Nursery who identified samples of winter twigs and leaves indicated 10 $\mathrm{m}$ tall would be considered above average height for the species.

According to Gordon Nelson of Kyle, his father, Elmer Nelson, the landowner, planted the tree in 1925 , before Clearwater Lake became a Regional Park. As you may note from the picture, the tree grows very close to the lake edge now surrounded by vacation cabins. The source of the tree is unknown but the PFRA Tree Nursery at Indian Head was sending trees out for planting prior to 1925. Gordon Nelson cannot remember the size of the tree when it was planted. If a sapling of three years was planted, it is now nearly 65 years old. I could not find any information on longevity of this willow species, however, PFRA staff indicated that 65 years is old for this species of willow. Its size and age without doubt say something about the preferred habitat of the Laurelleaved Willow.

To give an idea of scale, the two people in the picture, taken $21 \mathrm{De}$ cember 1991, are my son Jeffrey (1 $\mathrm{m}$ tall) and nephew Brad Tyberg (1.8 $m$ tall), both of Swift Current.

\title{
ADDITIONS TO THE FLORA OF CYPRESS HILLS PROVINCIAL PARK WEST BLOCK IN SOUTH- WESTERN SASKATCHEWAN
}

\section{BERNARD DE VRIES, George F. Ledingham Herbarium, University of}

Regina, Regina, Saskatchewan. S4S OA2

The Cypress Hills are situated in the arid short-grass prairie in southwestern Saskatchewan, forming a high plateau on the plains of western Canada. The elevation of the plateau ranges from 870 to $1350 \mathrm{~m}$ and is bisected by a major valley, called the "Gap." The plateau consists of two parts, the centre block and the west block. The Cypress Hills are of interest because they support a rich and varied flora of montane and boreal species. Above $1300 \mathrm{~m}$ a coniferous forest occurs, similar to that in the southern Rocky Mountains.

In 1990, a study was designed to survey proposed logging areas in the centre and west blocks of the park, in order to assess the status of rare and endangered plants, their critical habitat and potential means for their preservation. This article documents three vascular and two non-vascular species new to the flora of the west block that were found during the study.

The earliest botanical reports for the Cypress Hills were made by John Macoun between 1880 and 1892. ${ }^{6}$ Breitung, Ledingham (pers. comm., 1991), de Vries and others have undertaken more recent floristic studies. ${ }^{2,3,4,5,7}$ 
The following annotated plant list was compiled personally by the author, except for the Sphagnum species which were identified by Dr. Dale H. Vitt, University of Alberta. Where possible, only a small sample was collected under permit and deposited at the George F. Ledingham Herbarium in Regina. Collection numbers and data follow each species. The nomenclature follow Scoggun and Vitt. ${ }^{9,10}$

\section{Musci - Sphagnales}

The discovery of a small Sphagnum population was surprising as it occurred not in a Sphagnum bog as found in the Rocky Mountains and northern boreal forest, but rather in a sedge (Carex) meadow surrounded by mixed forest.

Hypothetically, Sphagnum could have entered the unglaciated west block, when two major climatic events occurred: the Holocene warm period during which the isolation of the $\mathrm{Cy}$ press Hills from the Rocky Mountains and northern boreal forest may have taken place; or the shift to a cooler and wetter climate influencing the establishment of small "bogs" suitable to Sphagnum in Cypress Hills Provincial Park.

Sphagnum warnstorfii Russow (Peat-moss) No. 1991.12. Very rare. In shallow depression in sedge meadow. Previously reported for the centre block as Sphagnum warnstorfianum Du Rietz. 'The location adjacent to logging area No. 9 is now presumed to be lost due to clear-cutting of the immediate area. This will undoubtedly have a serious impact upon the ecosystem of the area and the critical habitat for this species.

\section{Musci - Bryales}

Plagiomnium ellipticum (Brid.) Kop. (which has also been listed as
Plagiomnium rugicum (Laur.) Kop.) No. 19,587. Collected once with Orchis rotundifolia Banks (Roundleaved Orchid) on small sedge hummock. Not previously recorded for the Cypress Hills. This site adjacent to logging area No. 9 is presumed lost due to logging of the immediate area.

\section{Lycopodineae - Lycopodiales}

Lycopodium annotinum L. var. annotinum (Stiff Clum-moss) No. 19,545. Observed once as a small colony in a shaded Lodgepole Pine and aspen woods. ${ }^{2}$

Lycopodium complanatum L. var. complanatum (Ground Cedar) No. 19,532. Discovered in shaded Lodgepole Pine ravine in block 50 , and again as a small population in blocks 9 and 57 in shaded Lodgepole Pine and White Spruce woods. Previously reported for the centre block. ${ }^{5}$

Botrychium virginianum (L.) Sw. var. virginianum No. 20,846. Rare. In shaded White Spruce and aspen woods at base of slope. One colony of three plants only. In proposed logging area 5 . Previously reported as occurring in aspen woods. ${ }^{2}$

Discussion The presence of relict boreal elements in the flora of southwestern Saskatchewan is always interesting, especially since Cypress Hills Provincial Park is isolated by vast expanses of grassland. How did these boreal and montane species arrive in Cypress Hills? Russell put forth the hypothesis that certain types of flora could have entered the Cypress Hills in early post-glacial time from the southwest following deglaciation to the northeast. ${ }^{8}$ Sphagnum and Lycopodium may have found a niche here at the same time, when climatic 
conditions favoured forest growth and the formation of Sphagnum "bogs." They became relict species when a warm climate regime isolated the Cypress Hills from the Rocky Mountains.

All species recorded above have a cosmopolitan distribution in the foothills, Rocky Mountains, and northern boreal forest but are very restricted in Cypress Hills Provincial Park.

\section{Acknowledgements}

The 1990/1991 study was jointly financed by the Saskatchewan Department of Parks and Renewable Resources (SPRR) and the Saskatchewan Natural History Society. Special thanks are extended to Mr. John Vandall and Mr. Bruce Walter of SPRR; Miss Chris Potter, park naturalist at Cypress Hills Park; and the administrative staff, for their cooperation and assistance. The author would like to thank Mrs. Irma Machmer for her tireless assistance with field work and encouragement during the 1991 floristic study.

1. BIRD, C.D. 1962. Bryophytes of the Cypress Hills Provincial Parks, Alberta and Saskatchewan. Canadian Journal of Botany 40:573-587.

2. BREITUNG, A.J. 1954. A botanical survey of the Cypress Hills. Canadian Field-Naturalist 68:55-92.
3. DE VRIES, B. 1990. Rare and endangered plants of Cypress Hills Provincial Park, a preliminary report. Saskatchewan Parks and Renewable Resources. Unpub. 12 pp.

4. - 1991. Rare and endangered plants and critical habitat study, Cypress Hills Provincial Park, Saskatchewan. Saskatchewan Parks and Renewable Resources. Unpub. 16 $p p$.

5. MACLAREN PLANSEARCH. 1980 Cypress Hills Provincial Park, centre block. Stage I, resource inventory assessment. Saskatchewan Department of Parks and Renewable Resources. Unpub. 34 pp.

6. MACOUN, J. 1883-1892. Catalogue of Canadian plants. Parts 1-7. Geological Survey of Canada, Ottawa.

7. PRAIRIE ENVIRONMENTAL SERVICES. 1985. Cypress Hills Provincial Park vegetation management plan. Saskatchewan Department of Parks and Renewable Resources. Appendices 1-11. $41 \mathrm{pp}$.

8. RUSSELL, L.C. 1951. Land snails of the Cypress Hills and their significance. Canadian Field-Naturalist 65: 174-175.

9. SCOGGAN, H.J. 1978. The flora of Canada. Part II. National Museum of Natural Sciences, Ottawa.

10. VITT, D.H., J.E. MARSH, and R.B. BOVEY. 1988. Mosses, lichens and ferns of northwestern North America. Lone Pine Publishing, University of Washington Press. 286 pp.

Through all this glorious country, the river ran its jungled course ... bringing water to the plains and marshes, flooding them with melted snow, replenishing them with silt and nutrients. Now nearly all of this balanced life is gone because you and I, and our parents and grandparents, said yes, or said no and were not heard, or said nothing. Braun \& Cavagnara. 1971. Living Water. American West, Palo Alto, CA. 